\title{
PORÓZUS DEKORATÍV KERÁMIATERMÉKEK ELŐÁLLÍTÁSI LEHETŐSÉGEINEK VIZSGÁLATA TÉGLAAGYAG ÉS ALUMÍNIUM-OXID POROK FELHASZNÁLÁSÁVAL
}

\author{
Kurovics Emese - Gömze A. László
}

\begin{abstract}
Absztrakt: Hagyományos téglaagyag és a müszaki kerámiaipari alapanyagként ismert alumíniumoxid felhasználásával a szerzök olyan új kerámia kompozitot fejlesztettek ki, amely felhasználható padlófütési rendszerek dekoratív burkolására. A porszerü alapanyagokból finom szemcsés fürészporral több összetétel alkalmazásával keverékeket készítettek, majd egytengelyủ porsajtolással henger formájú próbatesteket sajtoltak. A minták égetése $1050^{\circ} \mathrm{C}, 1150^{\circ} \mathrm{C}$ illetve $1250^{\circ} \mathrm{C}$-os maximális hömérséklettel történt elektromos fütésü kamrás kemencében. A szerzők által kapott vizsgálati eredmények jól mutatják a keverék összetétel és a hökezelési körülmények hatását az elkészült próbatestek zsugorodására, porozitására, hővezető-képességére, valamint a termék olyan fizikai tulajdonságaira is, mint a szín.
\end{abstract}

\begin{abstract}
By using conventional brick and aluminum oxide raw material, the authors have developed a new ceramic composite that can be used for decorative coating of floor heating systems. The powdery ingredients mixed with fine granular sawdust were mixed, and cylindrical specimens were compacted with uniaxial pressure. The samples were incinerated at a temperature of $1050^{\circ} \mathrm{C}, 1150^{\circ} \mathrm{C}$ and $1250^{\circ} \mathrm{C}$ in the electrically heated chamber furnace. The results obtained by the authors shows the effect of the mixture composition and the heat treatment conditions on the shrinkage, porosity and thermal conductivity of the prepared specimens as well as the physical properties of the product as the color.
\end{abstract}

Kulcsszavak: agyag, alumínium-oxid, burkolólap, porsajtolás, égetés, porozitás, hővezető-képesség Keywords: clay, alumina, tiles, pressing, burning, porosity, thermal conductivity

\section{Bevezetés}

Napjainkban egyre jobban előtérbe kerül a dekoratív belső terek kialakításának igénye. A különbözö kerámia burkoló lapok felhasználásával egyedi és esztétikus környezet hozható létre. Emellett a padlófütési rendszerek egyre nagyobb teret hódítanak, amely megfelelő kivitelezéssel gazdaságos megoldást nyújt a helyiségek fütésére, és használatukkal az optimális hőérzet is hamarabb elérhető. A padlófütések esetén a jó hövezető képességgel rendelkezỏ kerámia járólapok segítségével a rendszer teljesítménye növelhető (Novais et al., 2014; Kurovics et al., 2016)

A hagyományos kerámia iparban fontos szerepet kapnak a biológiai eredetű pórusképző adalékok mind a technológiai folyamat során, mind a kész termék minöségét tekintve (Kurovics et al., 2016; Bánhidi et al., 2008; Kristály-Gömze, 2008; Bories et al., 2015; Rubia-García et al., 2012; Géber et al., 2010) A téglaipari termékek esetén fontos szerepük van a szilárd részecskék között található réseknek, pórusoknak, amelyek a termékek hőszigetlő-képességének javítását célozzák (Kadir et al., 2014). A fürészpor és más biológiai eredetű hulladékanyagok felhasználásával könnyített szerkezetü (porózus) agyagtéglák, burkolólapok készíthetőek (GömzeGömze, 2008; Kadir et al., 2015). 
Jelen kutatás célja olyan porózus kerámia burkolólap fejlesztése magyar alapanyagok (agyag, alumínium-oxid, fürészpor) felhasználásával, amely alkalmas padlófütési rendszerek támogatására.

\section{Anyag és módszer}

A kutatás során hagyományos szürke téglaagyagot (Leier Mátraderecske) és MARTOXID KMS-94 alumínium-oxidot (Martinswerk) használtak fel a szerzők. A kísérlet elött az agyagot $110^{\circ} \mathrm{C}$-on 24 órán át szárították, majd az alakadáshoz szükséges szemcseméretre aprították. Ezt követően az alapanyagok kimérése az 1. táblázatnak megfelelően történt. Az különböző összetételü alumínium-oxid agyag keverékekhez pórusképzö adalékanyagként $0 \mathrm{~m} \%, 4 \mathrm{~m} \%$ és $8 \mathrm{~m} \%$ finom szemcsés fürészport adagoltak. A fürészpor hozzáadása a porozitás növelését, illetve az égetésnél a szükséges fütőanyag mennyiségének a csökkentését is szolgálja.

\section{2. táblázat: A keverékek összetétele tömegszázalékban}

\begin{tabular}{|c|c|c|}
\hline \multicolumn{3}{|c|}{ Összetétel [m\%] } \\
\cline { 1 - 2 } Agyag & $\mathrm{Al}_{2} \mathrm{O}_{3}$ & \multirow{2}{*}{ Fürészpor } \\
\hline 100 & 0 & \\
\cline { 1 - 2 } 0 & 20 & \multirow{2}{*}{0} \\
\cline { 1 - 2 } 60 & 40 & \multirow{2}{*}{8} \\
\hline 40 & 60 & \\
\hline 20 & 80 & \\
\hline 0 & 100 & \\
\hline
\end{tabular}

A keverékekből egyoldalú porsajtolással történt a vizsgálatokhoz szükséges 20 mm átmérőjü henger formájú próbatestek alakadása $220 \mathrm{MPa}$-os sajtoló nyomással. A sajtolt kerámia próbatestek hökezelése (égetése) $1050^{\circ} \mathrm{C}, 1150^{\circ} \mathrm{C}$ és $1250^{\circ} \mathrm{C}$-os maximális hömérséklettel történt, kamrás kemencében. Az eltérō összetétel és hőkezelés hatására a minták színe jelentős eltérést mutat, ez látható az 1. ábrán.

A próbatestek tömegét és geometriai méreteit az égetés előtt és után is megmérték, amely alapján a szerzők meghatározták a minták térfogati zsugorodását. $\mathrm{Az}$ égetett termékek vízfelvétele Archimédeszi módszerrel, míg a hővezetési tényezője C-Therm TCi (Thermal Conductivity Analyzer) méröberendezéssel lett meghatározva. A próbatestek töretfelületének mikroszerkezetét Hitachi TM-1000 típusú pásztázó elektronmikroszkóp segítségével vizsgálták. 
3. ábra: A próbatestek az égetés után (Kurovics et al., 2016)

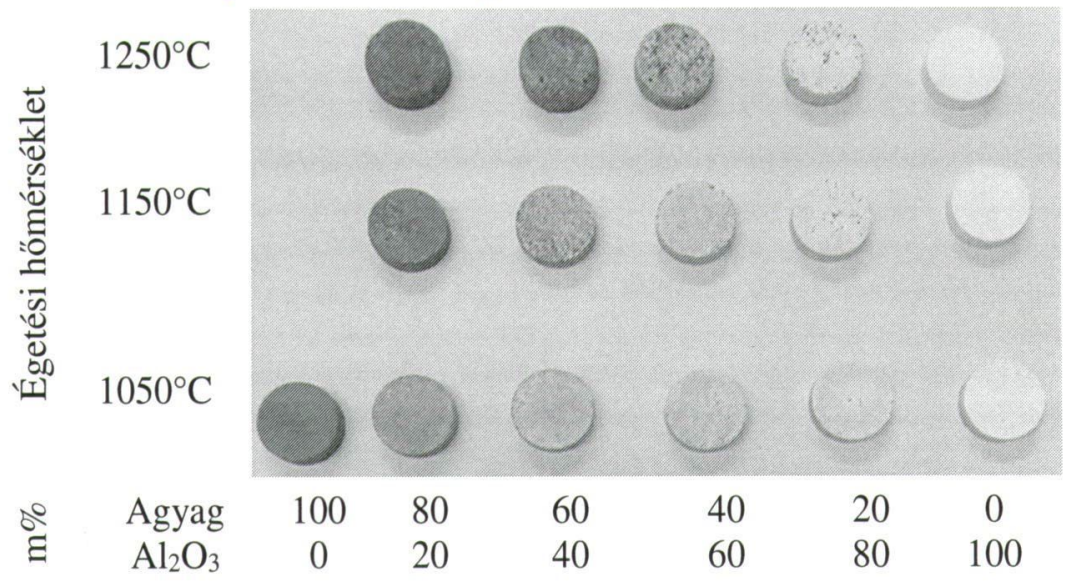

\section{Eredmények és értékelésük}

$\mathrm{Az}$ alacsonyabb hőmérsékletü égetések során $\left(1050^{\circ} \mathrm{C}\right.$ és $\left.1150^{\circ} \mathrm{C}\right)$ a minták zsugorodása hasonló tendenciát mutat, viszont a hőmérséklet növelésével jelentős eltérés tapasztalható. Az égetés során bekövetkező térfogatváltozás látható az alumínium-oxid és a fürészpor tartalom függvényében a következő ábrákon.

\section{4. ábra: $\mathbf{A z} 1150^{\circ} \mathbf{C}$-on (a) és az $1250^{\circ} \mathrm{C}$-on (b) égetett próbatestek térfogati zsugorodása az összetétel függvényében (Kurovics et al., 2016)}
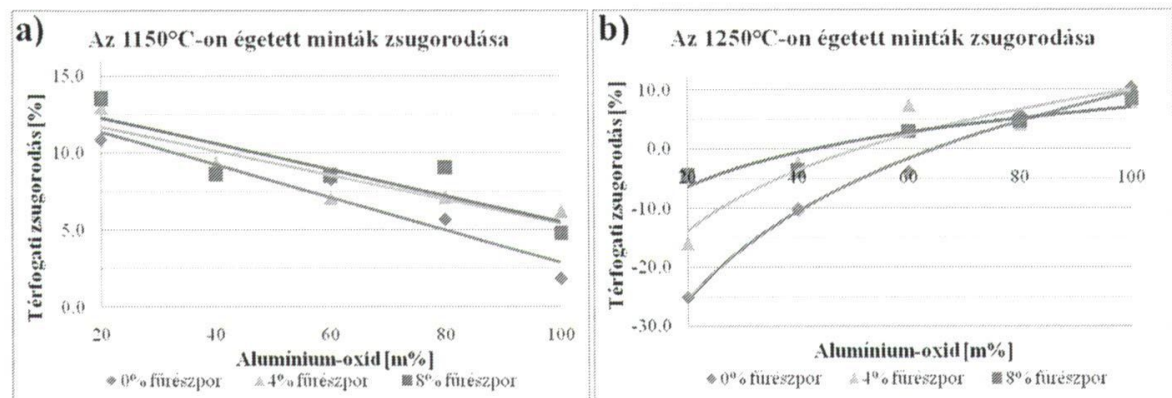

Általában az égetett kerámia termékek, téglák porózus mikroszerkezettel rendelkeznek, ami erősen függ az alkalmazott pórusképző adalékanyag mennyiségétől és minőségétől (fürészpor, rizshéj, napraforgómaghéj stb.) (Kalatur et al., 2014; Kulkov et al., 2014). A fürészpor hozzáadásával nagyobb mértékü zsugorodás tapasztalható minden keverék esetén.

A kerámiák vízfelvevő képessége függ a termék porozitásának mértékétől. A próbatestek vízfelvétel változását a 3. ábra mutatja összetétel szerint. 


\section{5. ábra: $\mathbf{A z} 1050^{\circ} \mathrm{C}$-on (a) és az $1150^{\circ} \mathrm{C}$-on (b) égetett próbatestek vízfelvevő- képessége az összetétel függvényében (Kurovics et al., 2016)}
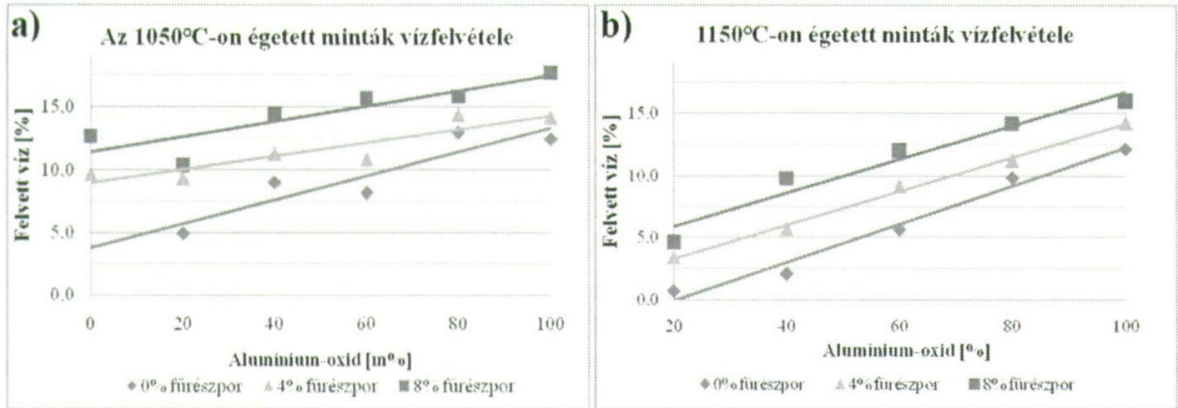

$\mathrm{Az} 1050^{\circ} \mathrm{C}$-on égetett próbatestek esetén a $4 \mathrm{~m} \%$ fürészport tartalmazó keverékek vízfelvételét kevésbé befolyásolja az $\mathrm{Al}_{2} \mathrm{O}_{3}$-tartalom. $\mathrm{Az}$ égetési hömérséklet növelésével ez megváltozik, a magasabb agyagtartalommal rendelkező minták esetén erősen lecsökken. A különböző keverékek, illetve próbatestek vízfelvevő tulajdonsága a fürészpor mennyiségének növelésével növekedett mindhárom hőmérsékleten.

\section{6. ábra: $\mathbf{A z} 1050^{\circ} \mathrm{C}$-on (a) és az $1150^{\circ} \mathrm{C}$-on (b) égetett próbatestek hővezetési} tényezője az összetétel függvényében (Kurovics et al., 2016)
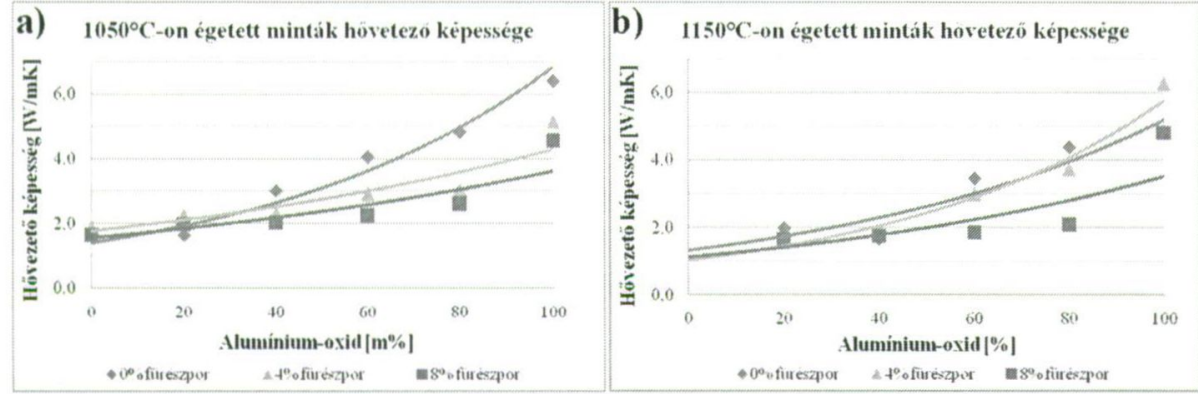

A kerámia termékek hővezetési tényezőjét $(\lambda)$ befolyásolja a porozitás, a pórusok elhelyezkedése (Bánhidi et al., 2008). Az agyag, illetve a tiszta alumíniumoxid hővezető képessége igen eltérő. Az agyag felhasználása során, mint téglaipari alapanyag a minél nagyobb hőszigetelő képesség elérése fontos. Az alumínium-oxid ezzel szemben jó hővezetőként ismert. Így a két anyag keverékéből készülő termékek esetén az összetétel függvényében változik a hővezetési tényező. Az agyag mennyiségének csökkentésével folyamatosan növekszik a $\lambda$ értéke. A porozitás növelése - nagyobb fürészpor mennyiség - javítja a késztermék höszigetelö tulajdonságát, ami a burkoló anyagoknál is fontos. 


\section{7. ábra: Töretfelületek SEM felvételei 1000-es nagyítással}
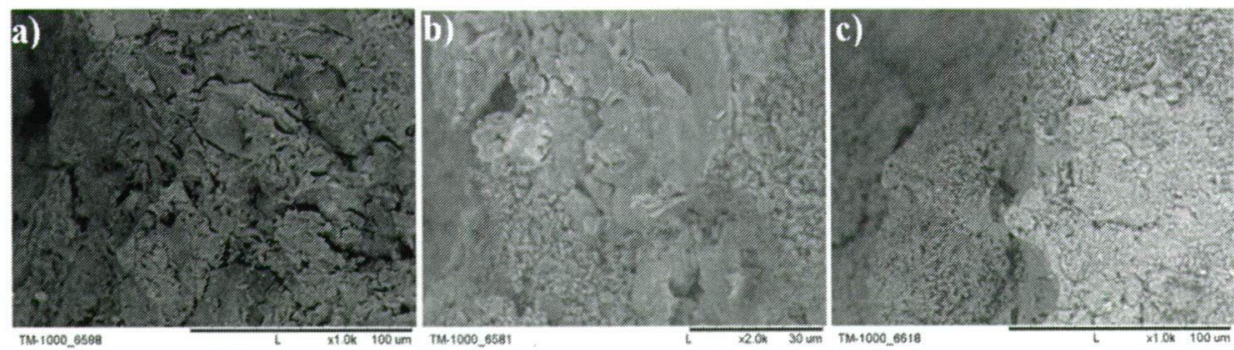

a) $100 \%$ agyag $4 \%$ fürészpor; b) $80 \%$ agyag, $20 \%$ alumínium-oxid és $4 \%$ fürészpor; c) $60 \%$ agyag, $40 \%$ alumínium-oxid és $2 \%$ fürészpor

A SEM felvételeken jól megkülönböztethető a két fő összetevő szemcseszerkezete. Az alumínium-oxidot határozott élekkel rendelkező sokszögü szemcsék alkotják, mivel az alacsony égetési hőmérséklet miatt nem alakultak ki a megfelelő kötések a szemcsék között, így összesajtolt szemcsehalmaz látható.

\section{8. ábra: Töretfelületek SEM felvételei 1000-es nagyítással}
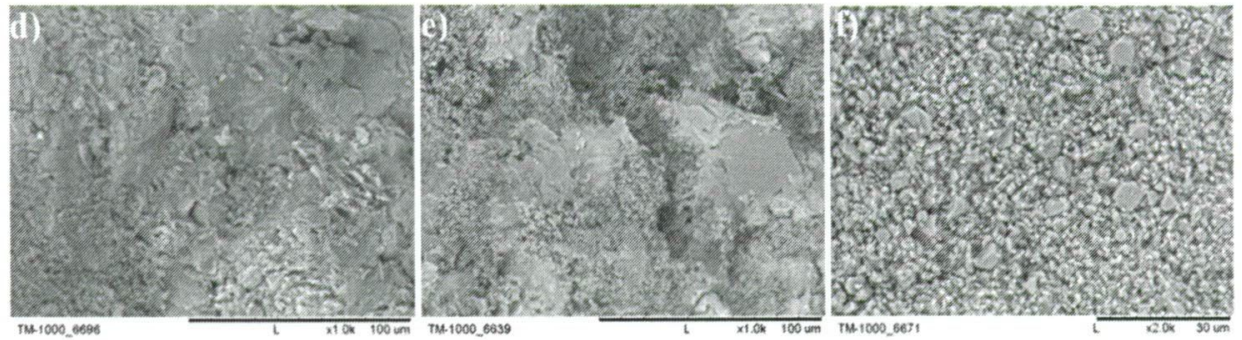

d) $40 \%$ agyag, $60 \%$ alumínium-oxid és 2\% fürészpor; e) $20 \%$ agyag, $80 \%$ alumínium-oxid és $4 \%$ fürészpor, f) $100 \%$ alumínium-oxid (2000-es nagyítás)

\section{Következtetések}

Az égetett kerámia burkolólapok zsugorodása, vízfelvevő képessége, hővezetési tényezője erősen függ az alapanyagokból készült keverékek összetételétől és az alkalmazott égetési körülményektől (hőmérséklet). A kutatási eredményekből jól látható, hogyan változnak az említett tulajdonságai a kerámia termékeknek az alumínium-oxid tartalomtól függően. $\mathrm{Az}$ alumínium-oxid és fürészpor alkalmazásával megfelelően porózus és térfogati zsugorodás szempontjából jól kezelhető termék állítható elő. A különböző összetételek alkalmazásával igen esztétikus megjelenésű burkolat valósítható meg, fal- és padlóburkolatként egyaránt.

A kutatás eredményeként a szerzők porózus, anyagában színezett, jó hővezető képességű termékeket állítottak elő, amely jól alkalmazható padlófütési rendszerek burkolataként. 


\section{Köszönetnyilvánítás}

"A cikkben ismertetett kutató munka az EFOP-3.6.1-16-2016-00011 jelü „Fiatalodó és Megújuló Egyetem - Innovatív Tudásváros - a Miskolci Egyetem intelligens szakosodást szolgáló intézményi fejlesztése" projekt részeként - a Széchenyi 2020 keretében - az Európai Unió támogatásával, az Európai Szociális Alap társfinanszírozásával valósul meg"

\section{Irodalomjegyzék}

Bánhidi V., Gömze A. L. (2008): Improvement of Insulation Properties of Conventional Brick Products. Materials Science Forum, 589 (1).

Bories, C., Aouba, L., Vedrenne, E., Vilarem. G. (2015): Fired clay bricks using agricultural biomass wastes: Study and characterization. Construction and Building Materials, 91 (158).

Géber R., Kocserha I., Orosz V., Simon A., Paróczai C. (2010): Optimization of the Mixing Ratio of Two Different Clays Used for Ceramic Roof Tiles. Materials Science Forum, 659 (477)

Gömze A L, Gömze N L (2008): Építöanyag-JSBCM 60: 102 <http://dx.doi.org/ 10.14382/epitoanyag-jsbcm.2008.16>

Kadir A A, Sarani N A, Leman AM (2014): Testing on Building Material Using Waste Material in Fired Clay Brick. Materials Science Forum, 803 (330)

Kadir, A. A., Hinta, H., Sarani, N. A. (2015): The utilization of coffee waste into fired clay brick. ARPN Journal of Engineering and Applied Science 10 (15): 6289

Kalatur, E. S., Buyakova, S. P., Kulkov, S. N., Gotman, I., Kocserha, I. (2014): Porosity and mechanical properties of zirconium ceramics. Építöanyag-JSBCM 66:31

Kristály F., Gömze A. L. (2008): Remnants of organic pore-forming additives in conventional clay brick materials: Optical Microscopy and Scanning Electron Microscopy study. ÉpítöanyagJSBCM, 60 (34).

Kulkov, S. N., Dedova, E. S., Pedraza, F., Erdélyi J. (2014): The Influence of Temperature on the Properties of $\mathrm{ZrW}_{2} \mathrm{O}_{8}$. Épitöanyag-JSBCM 66: 35

Kurovics E., Buzimov, Y. A., Gömze A. L. (2016): Influence of raw materials composition on firing shrinkage, porosity, heat conductivity and microstructure of ceramic tiles. IOP Conf. Series: Materials Science and Engineering, 123: 012058 doi:10.1088/1757-899X/123/1/012058.

Novais, M. Rui, Seabra, P. M., Labrincha, A. J. (2014): Ceramic tiles with controlled porosity and low thermal conductivity by using pore-forming agents Ceramics International, 40 (8): 11637 11648.

Rubia-García, MD., Yerba-Rodríguez, Á., Eliche-Quesada, D., Corpas-Inglesias, F. A., LópezGalindo, A. (2012): Assessment of olive mill solid residue (pomace) as an additive in lightweight brick production. Construction and Building Materials, 36 (495) 